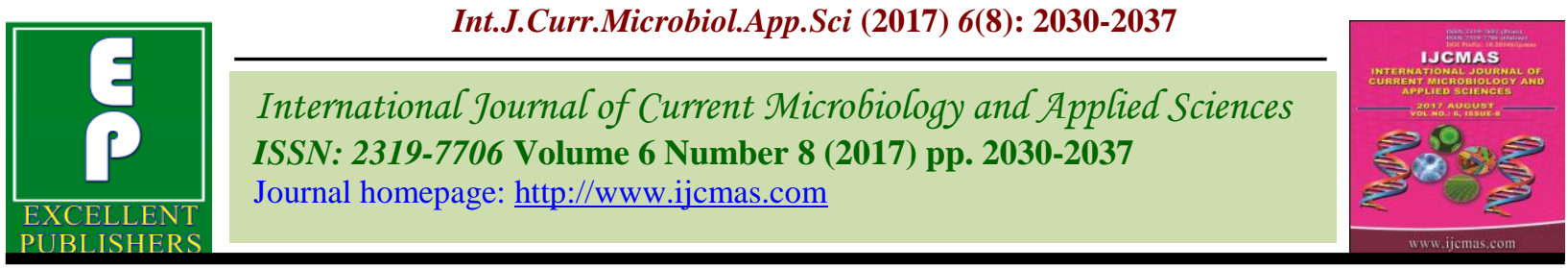

Review Article

https://doi.org/10.20546/ijcmas.2017.608.241

\title{
Transgenic Fruit Crops - A Review
}

\author{
P. Tanuja ${ }^{1}$ and Appani Laxman Kumar ${ }^{2 *}$ \\ ${ }^{1}$ Department of Fruit Science, College of Horticulture, Sri Kondalaxman Telangana State \\ Horticultural University, Telangana, India \\ ${ }^{2}$ Department of Fruit Science, College of Horticulture, Dr Y.S.R. Horticultural University, \\ Anantharajupeta, Andhra Pradesh, 534101, India \\ *Corresponding author
}

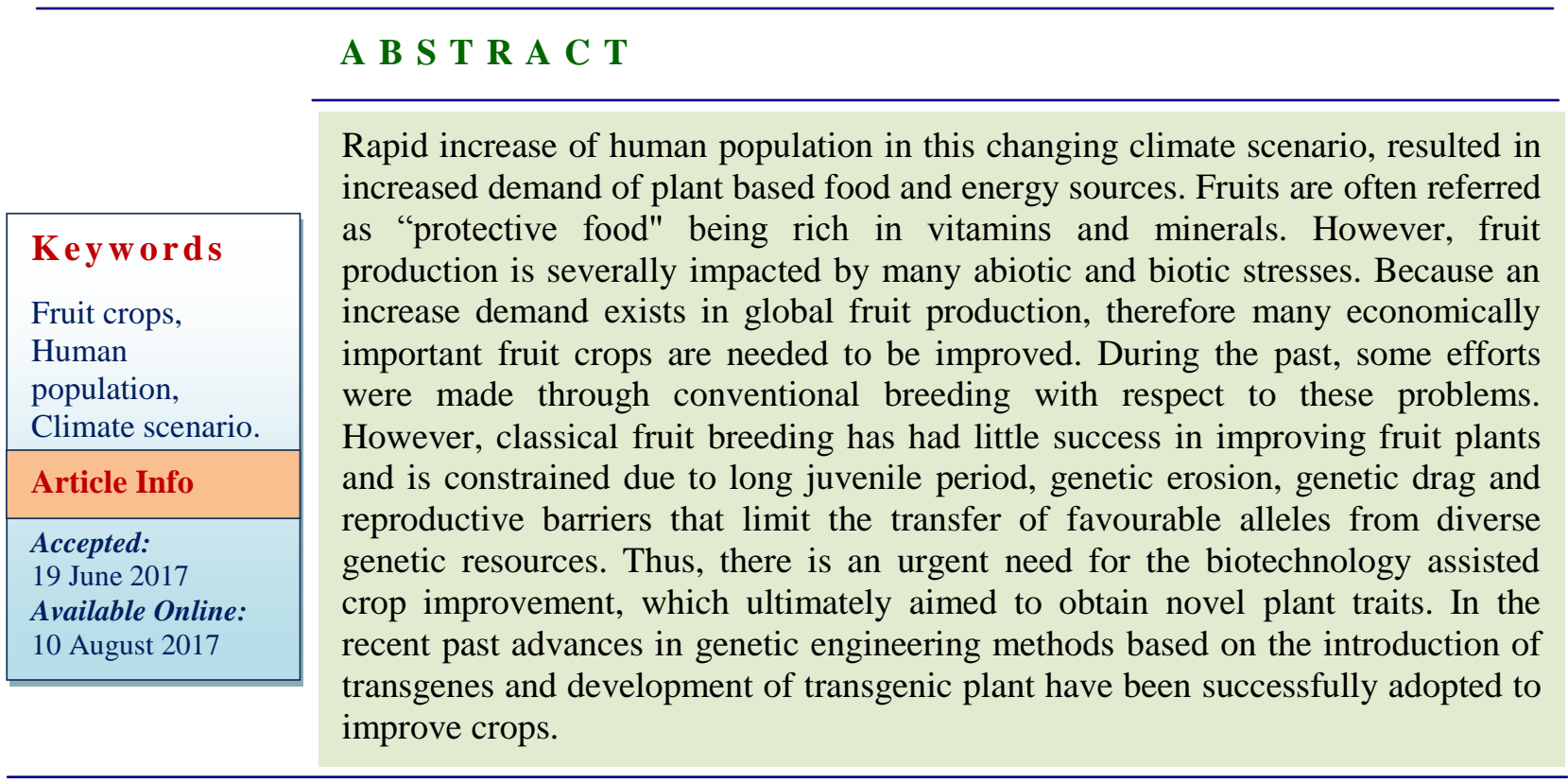

\section{Introduction}

Present increasing trend of population is alarming for food shortage. It was estimated that by the year of 2050 the population rate may increase up to 9 billion. Rapid increase of human population together with global climate variability resulted in increased demand of plant based food and energy sources. Conventional breeding is still limited due to genetic restrictions (high heterozygosity and polyploidy), long juvenile periods, self-incompatibility, resources restricted to parental genome and exposed to sexual combination.
Thus, there is an urgent need for the biotechnology-assisted crop improvement, which ultimately aimed to obtain novel plant traits. Plant genetic engineering has opened new avenues to modify crops, and provided new solutions to solve specific needs.

Contrary to conventional plant breeding, this technology can integrate foreign DNA into different plant cells to produce transgenic plants with new desirable traits. These biotechnological approaches are a great 
option to improve fruit genotypes with significant commercial properties such as increased biotic (resistance to disease of virus, fungi, pests and bacteria) or abiotic (temperature, salinity, light, drought) stress tolerances, nutrition, yield and quality (delayed fruit ripening and longer shelf life) and to use as bioreactor to produce proteins, edible vaccines and biodegradable plastics (Khandelwal et al., 2011).

\section{What are genetically modified organisms (GMO's)}

Genetically modified organisms are the one which the genetic material has been altered in such a way to get the required quality. This technology is called as Recombinant DNA technology or Genetic engineering. Genetically modified products include medicines, vaccines and foods.

Genetically engineered organisms are referred to as Transgenic or cisgenic organisms. The process of transfer, integration and expression of transgene in an organism is called transgenic transformation.

\section{Main features of transgenic plants}

Genes can now be transferred into plants from a wide range of organisms, including unrelated plant species, microbes, animals, and from DNA synthesized from laboratory.

In the year ahead, transgenic variety will be produced that have modification in a wide range of characters and have genetic changes not achievable through the conventional breeding methods. The features of transgenic plants are briefly discussed below:

\section{Contain transgenes}

Transgenic plant contains transgene (foreign gene). The foreign gene may be utilized from unrelated plant, microbes and animal. Microbial genes are utilized from fungi, bacteria and viruses. Sometimes, genes from DNA synthesized in the laboratory are also used for development of transgenic plants.

\section{Involved biotechnology}

Development of transgenic plants involves plant biotechnology, which refer to the combination of tissue culture and genetic engineering.

The foreign gene cannot be inserted into whole plants. It can only be inserted into single cells (tissue culture).

Thus combination of tissue culture and molecular genetics is essential for development of transgenic plants.

\section{Bypass sexual process}

In the development of transgenic plants, the sexual process is bypass. Transgenic plants are developed without involving sexual fusion between donor and the recipient parents. Once a transgenic plant is developed, the transgenic trait can be transferred to other genotypes through backcross method.

\section{Low frequency}

In most of the fruit crops, transgenic plants are recovered at a very low frequency. Hence, huge single cells or protoplasts have to be screened in the culture media for identification and isolation of transgenic cells. The transformed cells are identified by Polymerase Chain Reaction (PCR) technique.

\section{Utility}

Transgenic plants are developed to solve specific problems in crop plants such as development of plants resistance to diseases, 
insects, drought, frost, salinity and metal toxicity, improvement of keeping quality and development of male sterility, etc.

\section{Advantages of transgenic crop breeding}

\section{Rapid method of crop improvement}

Stable transgenic plant can be developed in 34 years, whereas it takes 12-15 years to develop a new variety through conventional methods of breeding.

\section{Overcome crossing barriers}

Transgenic breeding permits gene transfer between unrelated species and even between unrelated organisms.

For example, a freezing resistant gene has transfer from fish to cultivated tomatoes. Similarly, ovalbumin gene of chicken has been transfer in alfalfa for improving protein quality.

\section{Evolution of new genotypes}

Sometimes transgenic breeding may lead to evolution of altogether new plant species, because it permits gene transfer between various plant species. Thus, it will affect the process of natural evolution.

\section{Application}

It can be used for the genetic improvement of both autogamous and allogamous crop plants.

\section{Effectiveness}

Transgenic breeding has been found effective for the genetic improvement of monogenic characters only.

It has been found very effective in development of plants with resistance to various diseases, insects and herbicides. Both seed and vegetative propagated species can be improved through the use of transgenes.

\section{Disadvantages of transgenic crop breeding}

The main drawback of this method is that there is no control over the copy number and side of integration of foreign gene.

The high cost of equipments prohibits use of this method by many researchers for DNA transfer.

\section{Papaya (Carica papaya)}

Papaya ring spot virus resistant transgenic papaya has been developed and commercialized in 1998 in Hawaii, USA by Dr. Dennis Gonsalves and his team (Gonsalves, 1998). SunUp (SunUp x Kapoho) cultivars of transgenic papaya have been developed by cloning $\mathrm{CP}$ gene of mild strain of PRSV from Hawaii.

The embryogenic tissue was bombar tungsten particles coated with engineered DNA construct of the PRSVHA 5-1 CP gene using the gene gun. Fifteen months later, transgenic plants were obtained.

\section{Plum (Prunus domestica)}

Plum is one of the tree fruits threatened by Plum pox poty virus (PPV) a quarantine disease that causes fruit loss to plums and other stone fruits. The use of resistant cultivars represents the most effective solution to control sharka.

As an enhancement to classical breeding, genetic engineering was used to produce transgenic clones that contain the PPV coat protein $(\mathrm{CP})$ gene, applying the principle of pathogen derived resistance. A result of this effort was the development of a transgenic clone designated as C5 (cv. Honey Sweet). 


\section{Apple (Malus $x$ domestica)}

The "non-browning" apple is genetically engineered to keep from going brown after being cut. When apple flesh is cut and exposed to oxygen, it begins to brown. But the genetically modified apple or "Arctic Apple," is resistant to browning. The "non-browning" genetically modified apples are designed to look fresh when they're not. It was developed by silencing a gene in the apple (that controls browning) by inserting modified apple DNA. It is approved for sale by USDA in 2015 .

\section{Role of transgenic breeding}

\section{Edible vaccines}

Transgenic banana is one of the recent examples, where genes of antigenic protein of many deadly disease causing pathogens have been expressed in banana fruits. Thus children can be immunized only by feeding with this transgenic fruits, instead of painful injections for immunization.

\section{Biodegradable plastic}

Poly Hydroxy Butyrate (PHB) is used as a substrate for the production of biodegradable plastic. By transforming the Poly Hydroxy Butyrate genes into the plants, this could be produced on large scale and at a very low cost, which may reduce the threat imposed by polyethylene to the ecosystem.

\section{Pest management}

Fruit crops suffer from a variety of insect pests. It is possible to implement biotechnological approaches to manage insect pests in a rational, durable and eco-friendly manner.

Therefore, novel insecticidal proteins and their respective genes need to be identified and used in conjunction with $\mathrm{Bt}$ to prevent development of resistant insect. In addition, IPM will have to play a central role in sustainable horticulture.

Disease resistance, herbicide resistance, abiotic resistance etc. are the areas where transgenic breeding can be play an important role in imparting resistance in fruit crops.

Examples: In apple gene attacin (from Hyalophorace cropia) lysozyme (farm chicken) and cecropin B (from H. cecropia) can be used for disease resistance against Eriwinia amylovora.

Approved transgenic fruit crops

\begin{tabular}{|c|c|c|c|c|}
\hline Crop & Variety & Trait & Developer & Approval \\
\hline Papaya (Carica papaya) & SunUp & PRSV resistant & Cornell University & USA (1996) Canada \\
\hline Papaya (Carica papaya) & Rainbow & PRSV resistant & University of Florida & USA (2008) \\
\hline Plum (Prunus domestica) & Honey Sweet & PPV resistant & USDA ARS & USA (2009) \\
\hline Apple (Malus $x$ domestica) & Arctic apple & Non-browning & Okanagan & USDA (2015) \\
\cline { 2 - 5 } & Golden Delicious & & Specialty Fruits & \\
\hline
\end{tabular}

Improving shelf life of fruits

\begin{tabular}{|l|l|}
\hline Name of the crop & Gene \\
\hline Apple & ACC synthase, Attacin esterase, Polyglactononase, \\
\hline Banana & ACC synthase \\
\hline Strawberry & Acetolactate synthase, Chitinase, Glucanase, PG inhibitor protein \\
\hline
\end{tabular}


Table.1 Permits and notifications of transgenic fruits approved

\begin{tabular}{|c|c|c|c|}
\hline CROP & TRAIT & GENES & DEVELOPER \\
\hline Apple & $\begin{array}{c}\text { Reduced polyphenol } \\
\text { oxidase }\end{array}$ & PPO suppression transgene, nptII & Gebber farms \\
\cline { 2 - 4 } & $\begin{array}{c}\text { Non browning reduced } \\
\text { polyphenol oxidase }\end{array}$ & $\begin{array}{c}\text { Polyphenol oxidase antisense, } \\
\text { PGAS1, PGAS2 }\end{array}$ & Cornell university \\
\hline Banana & Bunchy top resistance & $\begin{array}{c}\text { Replicase associated protein, } \\
\text { replicase inverted repeat, nptII }\end{array}$ & University of hawaii \\
\hline Grape root stock & $\begin{array}{c}\text { Grapevine fanleafneo } \\
\text { virus resistance }\end{array}$ & $\begin{array}{c}\text { Coat protein gene,heat shock 90 } \\
\text { homologous gene, nptII }\end{array}$ & Cornell university \\
\hline Grape fruit & Aphid resistance & Agglutin coat protein, GUS. & $\begin{array}{c}\text { Texas agrilife } \\
\text { research }\end{array}$ \\
\hline Papaya & $\begin{array}{c}\text { Female to male (or) } \\
\text { hermaphrodite. }\end{array}$ & EST116, ESTS, FSH11, FSH19. & $\begin{array}{c}\text { Hawaii agriculture } \\
\text { research centre }\end{array}$ \\
\hline
\end{tabular}

Table.2 Important fruit crops in which transgenic plants are reported

\begin{tabular}{|c|c|c|}
\hline Sl. No. & Name of the fruits & Technology used and references \\
\hline 1 & $\begin{array}{c}\text { Banana(Musa sp) } \\
\text { Bluggoe (ABB group) } \\
\text { Cavendish clone(Grand Nine) }\end{array}$ & $\begin{array}{c}\text { PB, Sagi et al., } 1995 \\
\text { EP, Sagi et al., } 1994 \\
\text { PB + Agrobacterium cocultivation., May et al., } 1995\end{array}$ \\
\hline 2 & $\begin{array}{l}\text { Papaya (Carica papaya L.) } \\
\text { Variety sunrise Solo, kapoho, Solo, } \\
\text { Sunset, Maradol, Sunrise }\end{array}$ & $\begin{array}{l}\text { ABM, Yang et al., } 1996 \\
\text { Pang and Gandner, } 1998 \\
\text { PM, Fitch et al., } 1990\end{array}$ \\
\hline 3 & $\begin{array}{c}\text { Mandarin(Citrus reticulata }) \\
\text { Ohta, Ponkan } \\
\end{array}$ & $\begin{array}{c}\text { Electroporation, } \\
\text { Hidaka and Omura, } 1993\end{array}$ \\
\hline 4 & $\begin{array}{c}\text { Apple (Mulus sp) } \\
\text { Greensleeves, M-26, Grenny Smith, } \\
\text { Delicious, Royal Gala }\end{array}$ & $\begin{array}{l}\text { AMB, James et al., } 1989 \\
\text { Dandekar, } 1991\end{array}$ \\
\hline 5 & $\begin{array}{c}\text { Kiwi fruit (Actinidia diliciosa) } \\
\text { Variety(Hayward) }\end{array}$ & $\begin{array}{l}\text { PBM, Oliveira et al., } 1991 \\
\text { ABM, Uematsu et al., }\end{array}$ \\
\hline 6 & Grape (Vitis vinifera) & PB + ABM, Scroza et al., 1994 \\
\hline 7 & Avocardo (Persea americana Mill) & ABM, Cruz-Hernandez et al.,1998 \\
\hline 8 & Pear (Pyrus communis) & ABM, Merkulov et al., 1998 \\
\hline 9 & Peach (Prunus persica) & PB, Xiaojian et al., 1994 \\
\hline
\end{tabular}

Table.3 Transgenic fruit crops developed by Agrobacterium mediated transformation

\begin{tabular}{|l|l|l|l|l|}
\hline Species & Aim & Plasmid & Transgenes & References \\
\hline Orange & $\begin{array}{l}\text { Method } \\
\text { optimisation }\end{array}$ & pGA482GG & gusA, nptII & Oliveira et al., 2009 \\
\hline Citrus sinensis & Resistance to virus & pBin19-sgfp & nptII, sgfp, p23 & Fagoaga et al., 2006 \\
\hline Citrus aurantifolia & $\begin{array}{l}\text { Enhanced salt } \\
\text { tolerance }\end{array}$ & pBin438 & nptII, AhBADH & Fu et al.,2011 \\
\hline Poncirus trifoliate & $\begin{array}{l}\text { Resistance to } \\
\text { PRSV }\end{array}$ & pRPTW & $\begin{array}{l}\text { PRSV replicase gene, } \\
\text { neo }\end{array}$ & Chen et al.,2001 \\
\hline Papaya & $\begin{array}{l}\text { Method } \\
\text { optimisation }\end{array}$ & pBIN19-sgfp & nptII, gfp & Terakami et al., 2007 \\
\hline Pomegranate & $\begin{array}{l}\text { Modulation } \\
\text { fruit softening }\end{array}$ & pBI121 & $\begin{array}{l}\text { antisense of endo-b- } \\
1,4-\text { glucanase }\end{array}$ & Lee \& Kim,2011 \\
\hline Punica granatum & Fragaria spp.
\end{tabular}




\section{Papaya}

Transgenic papaya has been developed against papaya ring spot virus using coat protein mediated resistant in university of Hawaii by Dennis Gonsalves. The coat protein gene from PRSV was isolated, cloned and used for transforming papaya to provide resistance against the severe strain of the same virus.

The target cultivars used in transforming papaya were the Red fleshed, Sunset and the Yellow fleshed kopoho. Transformation with coat protein gene is done using micro projectile bombardment technique using embryonic tissues of papaya. Two transgenic lines Sun UP from Sunset and UH Rambow from Kapoho were developed which have shown excellent resistance to PRSV.

Yun et al., (2005) conducted in vitro pathogen inhibition assays to show that Resveratrol inhibited fungal pathogens of papaya. Resveratrol at $1.0 \mathrm{mM}$ in the V8 agar culture medium inhibited mycelia growth of P.palmivora to $50 \%$ of control. The compound was shown to be active against $P$. palmivora at concentrations as low as 0.1 $\mathrm{mM}$.

But Resveratrol was not as effective against the anthracnose pathogen, Colletotrichum gloeosporiodes. At $1.0 \mathrm{mM}$ concentration, Resveratrol inhibited Collectotricum by only $10 \%$. The growth of Phytophthora capsici was also significantly inhibited by resveratrol.

\section{Banana}

Sunil et al., (2005) conducted Polyclonal antibody based ELISA analysis of transgenic banana plants grown in in vitro and in green house. This result suggests that ethylene enhances the expression of the antigen from the ethylene forming enzyme promoter. HBs
$\mathrm{Ag}$ expression was higher, when EFE promoter was used compared to ubq3 promoter in in vitro conditions.

\section{Grape}

Lucia et al., (2007) conducted an experiment to know thefecundity and total fruit production of Thompson seedless (TS) and Silcora (s) Def H9iaam lines (GM) in comparison with control. Thompson Seedless DefH9-iaaM line had twice as many bunches per plant than its control.

The increase in bunch number depends on the increased number of inflorescences per shoot detected in the transgenic line In the transgenic Thompson Seedless line, the number of berries per bunch was $30 \%$ more than its control. Although the average berry weight was slightly lower in the DefH9-iaaM Thompson Seedless line in comparison with the control, the average weight of the DefH9iaaM Thompson Seedless bunch was 25\% more than the control.

\section{Strawberry}

Silvia et al., (2002) conducted an experiment to know external and internal firmness in controls and transgenic strawberry Apel plants. The main differences between Apel and control fruits were observed in firmness. Fifty percent of the Apel clones analyzed showed a higher external fruit firmness than fruits obtained from control plants.

It is noteworthy that most of the Apel lines displayed a statistically significant increment in the internal fruit firmness (obtained after removing the external skin of the fruit), ranging the increment from $149 \%$ to a $179 \%$ when compared with macro propagated plants. The differences in firmness were not due to a reduction in Apel fruit weight. 


\section{Pineapple}

Sripaoraya et al., (2001) studied Genetic manipulation of pineapple for resistance to the herbicide Basta. Non-transformed plants remained green only at Basta2 concentrations less than $3 \mathrm{mg}$ lÿ1 glufosinate ammonium. The effect of Basta 2 concentrations in excess of $3 \mathrm{mg}$ lÿ1glufosinate ammonium on nontransformed plants was observed within 4 days of herbicide application, with inhibition of growth and loss of pigmentation. After 7 days the leaves of all Basta2 treated nontransformed plants were chlorotic and died rapidly, whereas all PPT-resistant plants and their clones remained green. Spray application of Basta2 at $100 \mathrm{mg}$ lÿ1 of glufosinate ammonium to the leaves of nontransformed plants resulted in tissue necrosis after 4 days followed by extensive browning within 14 days and death. In contrast, treated leaves of PPT-tolerant plants and their clones remained green.

\section{Apple}

Kenong et al., (2013) conducted a study to know the relative suppression of PPO activities in Arctic Apples. They have taken the two apple varieties that are Artic granny smith, Artic golden delicious which are transgenic they have analysed PPO suppression in the different plant organs like leaves, immature fruit, mature fruit. Among these the leaves has shown suppression of about (76-82 \%), immature fruit (94\%), and mature fruit $(90-91 \%)$.

\section{Plum}

Hilly et al., (2007) conducted a study for plum pox virus detection in transgenic Prunus domestica line intron -hair-pin-RNA-B14 from leaves 60 days after aphid mediated inoculation. The siRNA accumulation levels in the ihpRNA-B14 clone were found to be similar to C5 Prunus domestica suggesting that the clone would be highly resistant toplum pox virus. To verify that hypothesis, small rooted plantlets of ihpRNA-B14plum, one month from in vitro culture, were inoculated with plum pox virusby being exposed to viruliferous aphids. Two months after inoculation, all seven plantlets analyzed were symptomless and tested negative for plum pox virus by ELISA (Tables 1-3).

In conclusion, Fruits are the rich sources of vitamins and the other nutrients, these sources can be improved by the means of this transgenic breeding. Genetically modified crops offer dramatic promise for meeting the great challenges of twenty first century. Transgenic breeding help us for trait specific breeding, it can be a tool to increase productivity. The transgenic foods are safe to human as there is no scientific report on health and environmental hazards, since nutritionists and scientists have taken care of safety issues.

\section{References}

Hily, J. M., Ravelonandro, M., Damsteegt, V., Bassett, C., Petri, C. and Scorza, R., 2007, Plum Pox Virus coat protein gene intron-hairpin-RNA (ihpRNA) constructs provide resistance to Plum Pox Virus in Prunus domestica. Journal of the American society for Horticultural science.132 (6): 850-858.

Kenong XU, 2013, an overview of Arctic apples: Basic facts and characteristics. New York Fruit Quarterly, 21 (3): 8-10.

Khandelwal, Kuruganti, K. and Ramanjaneyulu, G.V., 2011, Genetic Engineering in Indian Agriculture - An Introductory Handbook: 2-5.

Sunil Kumar G. B., Ganapathi, T. R., Revathi, J., Srinivas, L. and Bapatv. A., 2005, Expression of hepatitis B surface antigen in transgenic banana plants. 
Planta An International Journal of Plant Pathology., 222: 484-493.

Yun, J., Tang, C.S. and Moore, P., 2005. Increased disease resistance in papaya by transforming a pathogen inducible stilbene synthase gene. Acta Horticulture., 2: 107-110.

Silvia, J., Redondo, J., Blanco, J., Jose, L., Jose, M. and Aranda, L., 2002. Manipulation of strawberry fruit softening by antisense expression of a pectatelyase gene. Plant Physiology, 128: 751-759.

Sripaoraya, S., Marchant, R., Power, J. B. and Davey, M. R., 2001, Herbicide-tolerant transgenic pineapple (Ananas comosus) produced by micro projectile bombardment. Annals of Botany, 88: 597-603.

\section{How to cite this article:}

Tanuja, P. and Appani Laxman Kumar. 2017. Transgenic Fruit Crops - A Review. Int.J.Curr.Microbiol.App.Sci. 6(8): 2030-2037. doi: https://doi.org/10.20546/ijcmas.2017.608.241 